\title{
Elaboration of principles for developing technological systems for the finishing of gears
}

\author{
M.G. Storchak ${ }^{1} \bullet$ Yu.M. Danylchenko² \\ 1 - Institute for Machine Tools University of Stuttgart, Germany; \\ 2 - Igor Sikorsky Kyiv Polytechnic Institute, Kyiv, Ukraine
}

Received: 21 January 2019 / Accepted: 14 March 2019

\begin{abstract}
The service properties of gears are mainly formed at the stages of their finishing processing, such as gear grinding, gear shaving, final dimensional calibration, gear honing, smoothing, lapping, burn-in, etc. The main task of the technological systems synthesis for the gears finishing is to determine the optimal parameters and structure of the technological system that ensure the specified properties of the gears. This task is multivariate and is constrained by the absence of general principles for its solution, which determines the individual nature of the development. The proposed principles of design of technological systems for finishing processing on the basis of a system approach provides a solution to the problem of their synthesis in general, that is, by representing the technological system as a generalized design object. The synthesis method is implemented in the form of a logical design scheme, which is interpreted by the morphological model. This model is developed by decomposing the original design problem and regulates the synthesis of informational, optimization and algorithmic systems.
\end{abstract}

Keywords: Gear, technological system, synthesis, system approach, morphological model.

\section{Introduction}

One of the most common, demanding and time-consuming elements that determine the maintenance and technical performance of most mechanisms and machines are gears. They provide high accuracy of reproduction of a given law of motion, compactness, reliability and durability of the transmission. Because of the need to increase loads, speeds and operating temperature, requirements for reducing the weight and dimensions of machines and mechanisms, the gears are highly stressed. The gears often lose their performance due to fatigue-contact damage to teeth, breakage, jamming and other types of damage.

Technological methods are one of the most effective methods of providing the necessary service properties of such complex products. They provide the desired properties through the appropriate accuracy parameters of the gear rim of the wheels and the quality of the surface layer of their teeth. With other things being equal, the service properties of gear wheels are mainly formed at the stages of finishing treatment of the teeth of gears. Technological methods of finishing processing include: gear grinding, gear shaving, final dimensional calibration, gear honing, smoothing, lapping, burn-in, etc. A great deal of research has been devoted to the development, research, and application of these methods in industry. However, a significant part of the research performed is devoted either to the solution of individual narrow issues or to a comprehensive analysis of existing technological processes of finishing processing. This has limited the bulk of the research performed by an engineering search for design features that ensure the necessary flow of specified finishing processes. At the same time, in the development of specific technological processes for the manufacture of gears, the problem arises of ensuring the service properties of the product, determined by the conditions of operation of the gear, technical and economic indicators of technological processes. These requirements are met through the use of technological systems for finishing processing. These systems are a combination of functionally interacted technological equipment. They are intended for performance in specified production conditions of technological processes, the ultimate goal of which is the formation of precision parameters of the ring gear, macro- and microgeometry of the surface layer of teeth and its physical and mechanical parameters. Such a task is the task of synthesizing technological systems and, as a rule, is multivariate. There are quite a few studies on this issue. These studies are limited to either general recommendations for creating a set of technological systems for the full cycle of gear production, or for determining the structure and parameters of technological systems based on experimental dependencies, which does not allow generalizing these studies. 
The synthesis of technological systems means the determination of the optimal parameters of the machine pair and the structure of the technological process based on the analysis of the functioning of the technological system through a certain system for determining the desired parameters and structure of the technological system. To do this, it is necessary to transfer the initial point of engineering search from design solutions to the search for processes that provide the necessary properties of the desired technological system as a whole. Such capabilities have a system approach [5], [6], [8]. The methodological basis of the research is the provision on the modeling of finishing processes based on a system approach [1], [7], [10], [10]. The central point of this method, as well as any other design process based on the systems approach, is the study of the relationship between real or abstract objects of the designed (synthesized) system. This is done by modeling the finishing process.

\section{Aim}

Creating a common approach to the design of technological systems for the finishing processing of gears.

\section{Principles for developing technological systems}

The development process of technological systems for gear finishing was elaborated based on the principles of system methodology. In this way it is possible to see the subject of investigation as a whole [2], [4].

According to the system methodology [1], [2], the design object is a functional part of a particular supersystem or metasystem. In the design process, it is subject to a functional division by which functional subsystems, subsubsystems, etc. up to the formation of indivisible elements are separated, from which the final stage of formation can be obtained. The design object here is a technological system for the finishing of gears - $\mathrm{S}_{1}$, which is part of the metasystem $\mathbf{S}$. The metasystem $\mathbf{S}$ is a formation guaranteeing the viability of the system $\mathrm{S}_{1}$. From this point of view, the metasystem $\mathbf{S}$ consists of the following structural components except for $S_{1}$ : the maintenance system - $S_{2}$, the transport system $-\mathrm{S}_{3}$, the control system $-\mathrm{S}_{4}$ and the organizing system $-\mathrm{S}_{5}$. The metasystem $\mathbf{S}$ is defined as a continuous set of objects $\mathbf{M}=\left\{\mathrm{m}_{1}, \mathrm{~m}_{2}, \ldots, \mathrm{m}_{\mathrm{k}}\right\}$ on which the relation $R$ is realized with a predetermined property $\Omega$ [5]:

$$
\Omega: \Rightarrow S=\left[R\left(m_{i}\right)\right] \Omega
$$

The set $\mathbf{M}$ out of objects of the metasystem $\mathbf{S}$ consists of the above-mentioned systems $\mathrm{S}_{\mathrm{i}}$, of which the structure can be presented as follows:

$$
R: \sum_{i=1}^{n} S \subset\left(S_{1} \wedge S_{2} \wedge S_{3} \wedge S_{4} \wedge S_{5}\right)
$$

where $\wedge$ is the conjunction (logical product) [3].

The relation $R$ is the connection of the systems $S_{\mathrm{i}}$, determines the structure of the metasystem $\mathbf{S}$ and provides a set of its properties $\Omega$. It is defined with the set $\mathbf{R}$, which is classified by the number of components in the following relations:

$$
R: \Rightarrow \mathbb{R}=\left(\left\{\mathbb{R}\left(S_{i}\right)\right\},\left\{\mathbb{R}\left(S_{i}, S_{j}\right)\right\}, \ldots,\left\{\mathbb{R}\left(S_{i}, S_{j}, \ldots, S_{l}\right)\right\}\right)
$$

where $\mathbb{R}\left(S_{i}\right)$ is a set of individual relations of the $i$-th object of the metasystem $\mathbf{S} ; \mathbb{R}\left(S_{i}, S_{j}\right), \mathbb{R}\left(S_{i}, S_{j}, \ldots, S_{l}\right)$ are sets of two, three, etc. local relations on the level of the examined decomposition.

Hence, one, two, three, etc. local predicates P can be defined [4], describing the relations between the objects in the viability of the system at the first stage:

$$
\underset{\mathbb{M}}{\forall} P^{l} \underset{\mathbb{M}}{\exists}\left\{\left(P_{i}^{l}\right) \wedge\left(P_{i}^{l}, P_{j}^{l}\right) \wedge \ldots \wedge\left(P_{i}^{l}, P_{j}^{l}, \ldots, P_{k}^{l}\right)\right\}: \Rightarrow \mathbf{S} \subset S_{1} \wedge S_{2} \wedge S_{3} \wedge S_{4} \wedge S_{5}
$$

This equation (4) represents the relations and thus also the structure of the metasystem $\mathbf{S}$. The diagram in Fig. 1 shows the interaction of the objects in the metasystem $\mathbf{S}$ with regard to the technological system $\mathrm{S}_{1}$. The metasystem $\mathbf{S}$ and its objects are the environment for the technological system $S_{1}$. Thus, $S_{1}$ appears as a particular converter in the diagram, where matter, energy or information can be transforming substances. This depends on the sort of the object and the purpose of the design.

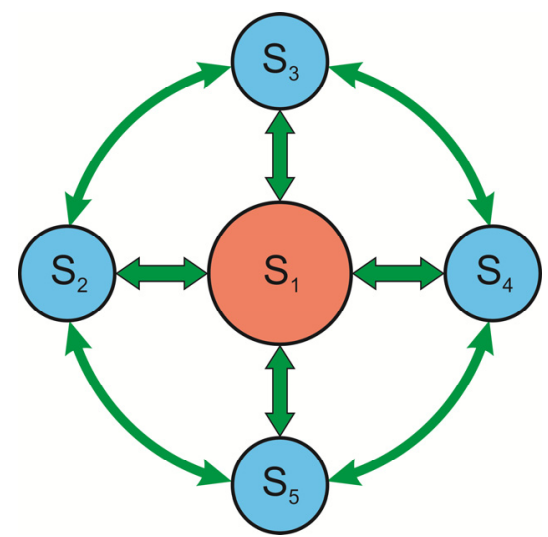

Fig. 1. Scheme of object interaction in the metasystem $\mathrm{S}$ with respect to the technological system $\mathrm{S}_{1}$ 
Upon its entry into the object, the flow of the substance to be transformed is divided into the functional process $\mathrm{F}_{\mathrm{S} 1}$ and the existence processes - Fig. 2.

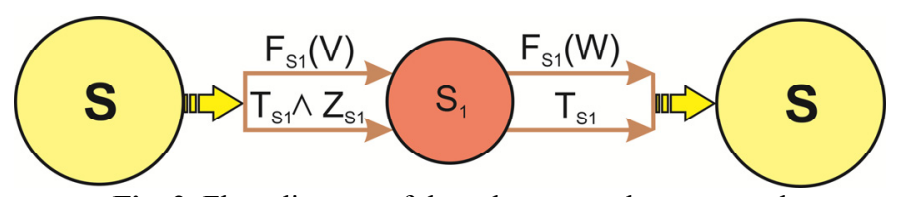

Fig. 2. Flow diagram of the substance to be converted

The latter represent the totality of the basic process $F_{\mathrm{S} 1}$ and the inherent processes $Z_{\mathrm{S} 1}$, guaranteeing the needs of the viability for the object. One part of the total transformation that the object $S_{1}$ performs for the needs of its metasystem $\mathbf{S}$ is called a function $\mathrm{S}_{1}$ in $\mathbf{S}$. This function $\mathrm{F}_{\mathrm{S} 1}$ connects the set of input parameters $\mathbf{V}$ for the functional process of the technological system with its set of output parameters $\mathrm{W}$ :

$$
F_{s}: \mathbb{V}(\mathbf{V}) \Rightarrow \mathbb{W}(\mathbf{W})
$$

where $\mathbf{V}=\left\{\mathrm{v}_{1}, \mathrm{v}_{2}, \ldots, \mathrm{v}_{\mathrm{n}}\right\} ; \mathbf{W}=\left\{\mathrm{w}_{1}, \mathrm{w}_{2}, \ldots, \mathrm{w}_{\mathrm{m}}\right\} ; \mathrm{v}_{\mathrm{i}}$ and $\mathrm{w}_{\mathrm{i}}$ are vectors and $i$ th elements of the corresponding input and output parameters.

Regarding the technological system $\mathrm{S}_{1}$ for the finishing of gears, the functional process is the conversion of the workpiece parameters into the parameters of the finished gear and the basic process is the actual process of finishing. The function $\mathrm{F}_{\mathrm{S} 1}$ describes the parametric system of the functional process - Fig. 3, and the basic process performs it:

$$
T_{S_{1}} \subset F_{S 1}: \mathbb{V}(\mathbf{V}) \Rightarrow \mathbb{W}(\mathbf{W})
$$

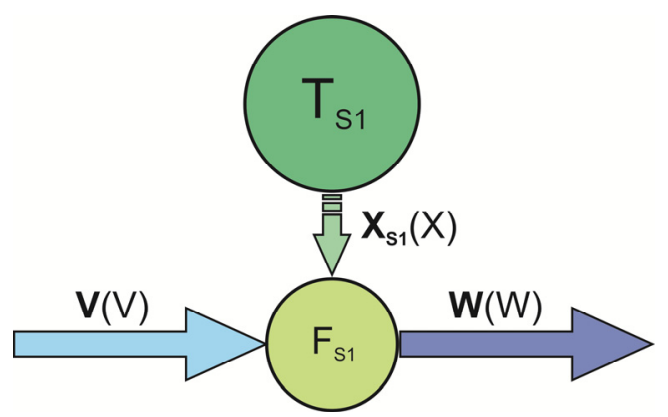

Fig. 3. Scheme of the parametric model of the functional process

The basic process is characterized by the set of parameters $\mathbb{X}_{\mathrm{s} 1}(\mathbf{X})$, where $\mathbf{X}=\left\{\mathrm{x}_{1}, \mathrm{X}_{2}, \ldots \mathrm{x}_{\mathrm{k}}\right\}$ is established by the structure $\Sigma$ on the defined level of decomposition and the function $\mathrm{F}_{\mathrm{S}}$ :

$$
\sum \wedge F_{S} \subset T_{S}: \mathbb{X}(\mathbf{X}) \Rightarrow \mathbb{W}(\mathbf{W})
$$

The formation of the set $\mathbb{X}$ determines the parametric model of the system's main process on the corresponding level of decomposition - Fig. 4. Thus, every level of decomposition $l$ can be defined by a two-digit predicate $P_{S}^{l}$ consisting of the structure $\Sigma$ and the set of parameters, which guarantee the function $\mathrm{F}_{\mathrm{S}}$ :

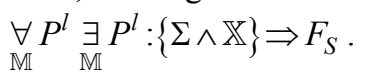

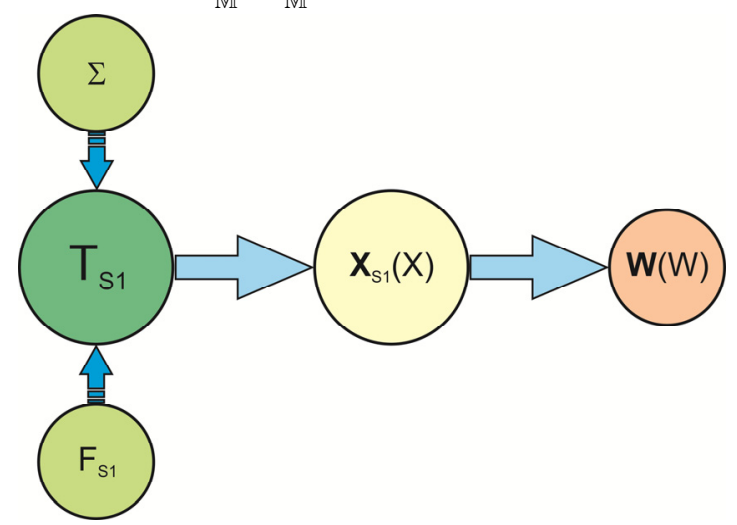

Fig. 4. Scheme of multiplicity $\mathbb{X}$ formation on the corresponding decomposition level

Correspondingly, every level of decomposition $l$ is described as structural and parametric model. Hence, the synthesis of a system can be interpreted as the determination of a predicate $P_{S}^{l}(8)$ on the level $l$ of the system or rather 


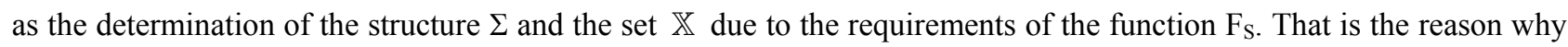
the predicate $P_{S}^{l}(8)$ can be established on a particular level of the system to be synthesized by means of the consistent identification of such predicates on every level of decomposition, starting with the lowest level:

$$
\underset{\mathbb{M}}{\forall} P_{\mathbb{M}}^{l} \exists P^{l}:\left\{P^{l} \succ \ldots \succ P^{3} \succ P^{2} \succ P^{1}\right\},
$$

where $\succ$ is the symbol of the sequence 3 .

For the synthesis of a system, a rule is to be postulated according to which the decomposition has to be carried out. This rule refers to the purpose of the synthesis to be performed. If the determination of optimum parameters for a technological system is understood as synthesis or if a parametric optimization of the synthesis is the final stage, then the rule can be formulated as follows:

Objects of the lower levels in the functional decomposition of a technological system for the finishing of gears are used as system elements, establishing the project parameters of mechanical gears and the machining conditions:

$$
\underset{\mathbb{M}}{\forall} \underset{\mathbb{M}}{\exists} P:\left\{\mathbf{S}^{l=\max } \wedge \stackrel{n}{S_{i}} \Rightarrow \mathbb{X}\right\},
$$

i.e. the parameters, which can be controlled by the designer. Owing to this rule, the functional decomposition of technological systems for the finishing of gears can be carried out. Such a decomposition is represented by structural equations of every level of decomposition as follows:

$$
\begin{cases}l=0 & \mathbf{S} \\ l=1 & \mathbf{S} \subset S_{1} \wedge S_{2} \wedge S_{3} \wedge S_{4} \wedge S_{5} \\ l=2 & S_{1} \subset M \wedge T \wedge W \wedge E \\ l=3 & M \subset T M \wedge W M ; T \subset N T \wedge K T \wedge W T ; W \subset N W \wedge K W ; E \subset T E \wedge W E\end{cases}
$$

where $\mathrm{M}$ is the machine tool; $\mathrm{T}$ is the tool; $\mathrm{W}$ is the workpiece; $\mathrm{E}$ is the device; $\mathrm{TM}$ is the kinematic chain of the tool; WM is the kinematic chain of the workpiece; NT is the tool hub; KT is the tool rim; WT is the working element of the tool; NW is the workpiece hub; KW is the gear rim of the workpiece; TE is the tool holder on the machine; WE is the workholder on the machine.

The system of the structural equations (10) together with the predicate (8) create a structural-hierarchical model of the technological system for the finishing of gears - Fig. 5. The model provides a basis for developing such technological systems. The objects of systematic investigations are the relations $R(2)$ between the system elements (8) and (10), generating the interactions available for the modelling. This makes it possible to guarantee a formalized regulation of the method for developing technological systems for the finishing of gears. The interactions of the elements of the model are established by the relation between the process $F_{S}$ of gear cutting and the objects of the technological system.

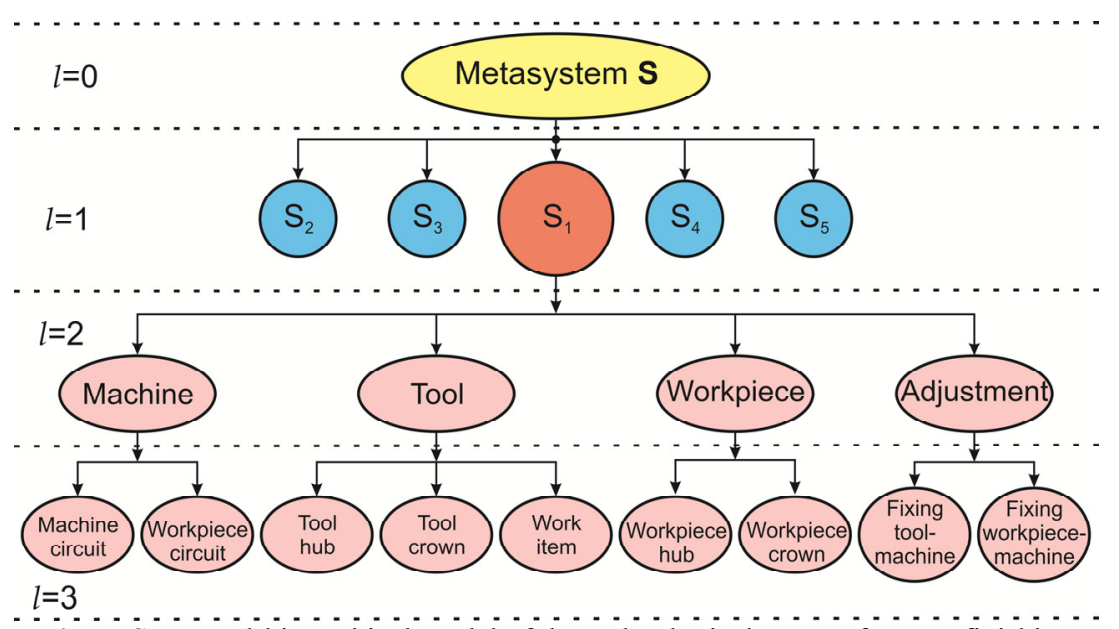

Fig. 5. Structural-hierarchical model of the technological system for gear finishing

This relation is represented in a graph:

$$
G=<(\Sigma \wedge \mathbb{X}), F_{S}>.
$$

The cusps of the graph are the sets of structure on a corresponding hierarchical level $-\mathrm{M}^{l}$. The relations consist of $\mathbb{X}$ as the set of project parameters, $F_{S}$ as the function, and $\mathbb{W}$ as the set of output parameters of the gear and the arcs to be machined. Fig. 6 depicts the graph $\mathrm{G}$ of the technological system for the finishing of gears. In accordance with the graph, the structure of the parametric model for the technological system is represented as follows: 


$$
\mathbb{X}:\left(x_{t m} \wedge x_{t w} \wedge x_{w m} \wedge x_{n t} \wedge x_{n k} \wedge x_{k t} \wedge x_{k w} \wedge x_{w t} \wedge x_{t e} \wedge x_{w e}\right) \Rightarrow F_{S} \rightarrow \mathbb{W},
$$

where $\mathrm{x}_{\mathrm{tm}}, \mathrm{x}_{\mathrm{tw}}, \mathrm{x}_{\mathrm{wm}}, \mathrm{x}_{\mathrm{nt}}, \mathrm{x}_{\mathrm{nk}}, \mathrm{x}_{\mathrm{kt}}, \mathrm{x}_{\mathrm{kw}}, \mathrm{x}_{\mathrm{wt}}, \mathrm{x}_{\mathrm{te}}, \mathrm{x}_{\mathrm{we}}$ are sets of the project parameters regarding the kinematic chain of the tool, the relative arrangement of tool and workpiece, the kinematic chain of the workpiece, the tool hub, the correlation between the tool hub and its gear rim, the gear rim of the tool, the correlation between the working element of the tool and its gear rim, the working element of the tool, the connection of the tool holder with the tool and the connection of the workholder with the machine.

According to Equation (12), the parametric model of the machining process can be shown by a graph - Fig.7.

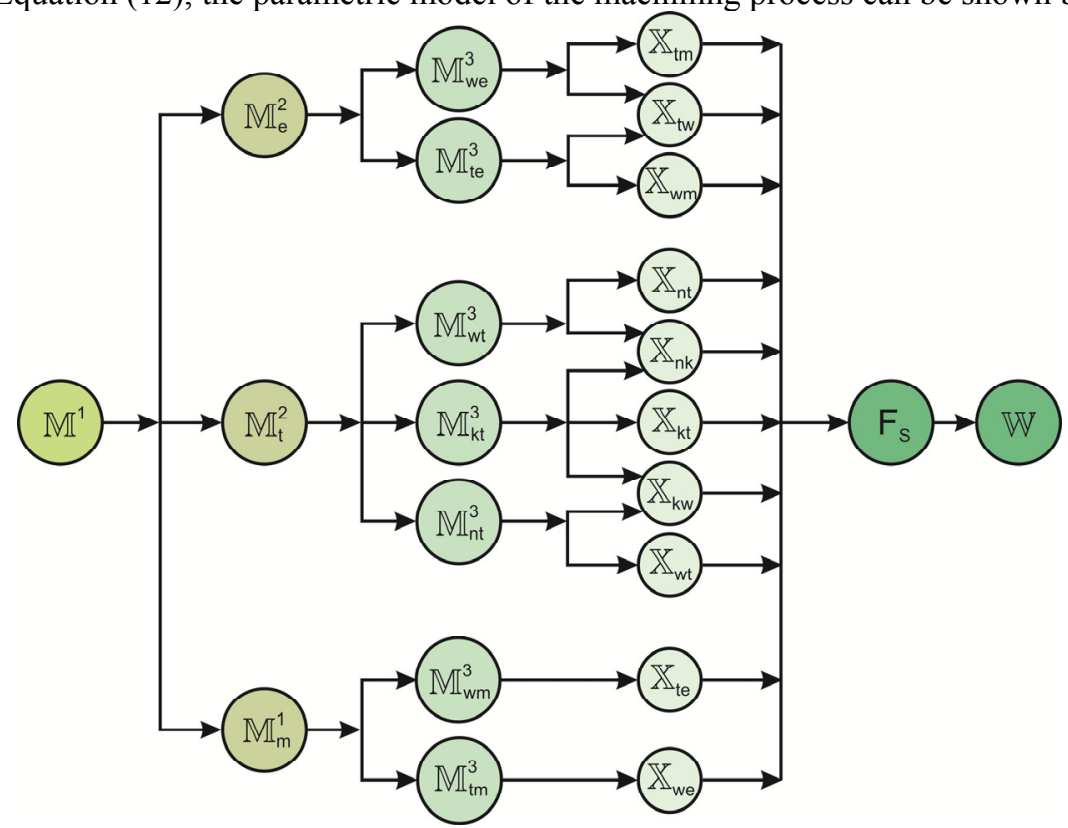

Fig. 6. Graph $\mathrm{G}$ of the technological system for gear finishing

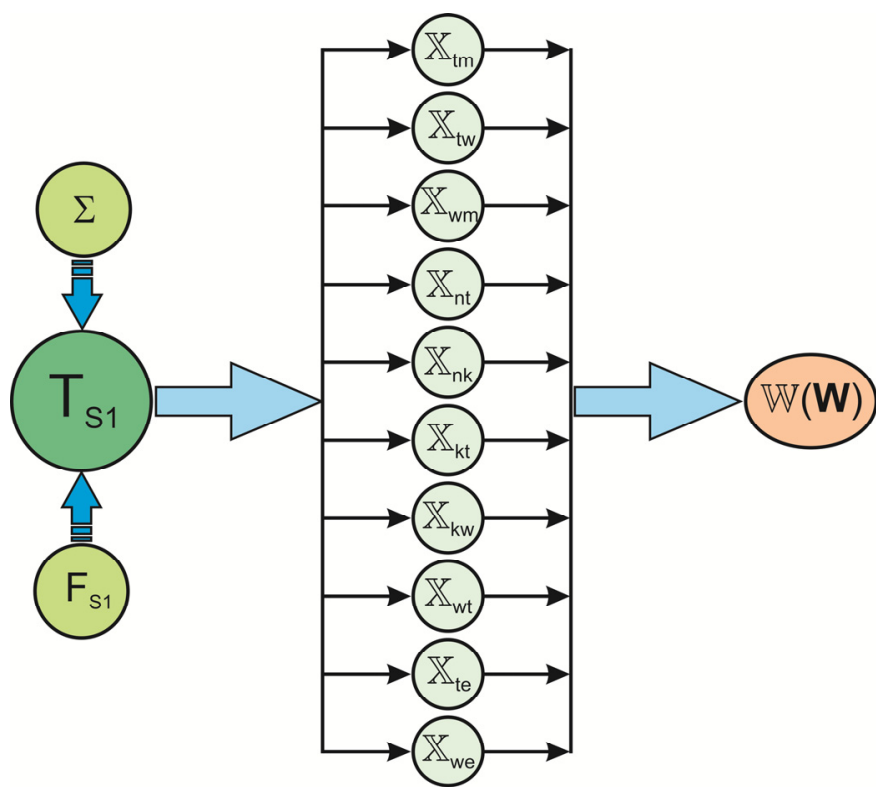

Fig. 7. Parametric model of the main process

The efficiency of the project parameter sets and their elements varies, depending on the structure $\Sigma$ of the technological system and the function $F_{S}$. In this case, the function $F_{S}$ represents an assessment or a criterion of the solution. The sets $\mathbb{X}$ for the structure $\Sigma$, which is represented by Equations (8) and (10), are identified as follows:

$$
\left\{\begin{array}{l}
\mathbb{X}_{t m}=\left\{n_{0}, V_{r e l}, S_{0}, t\right\} ; \mathbb{X}_{t w}=\{\gamma, \phi\} ; \mathbb{X}_{w m}=\left\{n_{1}, S_{f}\right\} ; \\
\mathbb{X}_{n t}=\left\{m_{c 0}, J_{c 0}, d_{c 0}, b_{c 0}\right\} ; \mathbb{X}_{n k}=\left\{C_{i 0}, h_{i 0}\right\} ; \\
\mathbb{X}_{t m}=\left\{z_{0}, \beta_{0}, b_{0}, \alpha_{n w 01}, \alpha_{0}, m_{0}, J_{0}, d_{a 0}\right\} ; \mathbb{X}_{k w}=\left\{C_{\text {eng }}, h_{\text {eng }}\right\} ; \\
\mathbb{X}_{t m}=\left\{C_{c u t}, h_{c u t}, M_{c m}, G_{c m}, C_{c m},\right\} ; \mathbb{X}_{t e}=\left\{C_{m}, h_{m}\right\} ; \mathbb{X}_{w e}=\left\{C_{s m}, h_{s m}\right\},
\end{array}\right.
$$


where $\mathrm{n}_{0}$ is the rotational speed of the tool; $\mathrm{V}_{\text {rel }}$ is the relative displacement velocity of the tool and workpiece profiles; $\mathrm{S}_{0}$ is the roll rate; $\mathrm{t}$ is the depth of cut; $\gamma$ is the crossing angle of the rotational axes of the tool and the gear to be machined; $\phi$ is the coordinate for the relative position of tool and gear in Z-direction; $\mathrm{n}_{1}$ is the rotational speed of the workpiece; $\mathrm{S}_{\mathrm{f}}$ is the feed rate of the workpiece; $\mathrm{m}_{\mathrm{c} 0}$ is the mass of the tool hub; $\mathrm{J}_{\mathrm{c} 0}$ is the tool hub's moment of inertia; $\mathrm{d}_{\mathrm{c} 0}$ is the outside diameter of the tool hub; $b_{\mathrm{c} 0}$ is the width of the tool hub; $\mathrm{C}_{\mathrm{i} 0}$ is the coupling stiffness of the tool hub with its rim; $h_{i 0}$ is the damping coefficient of the tool hub's coupling with its rim; $z_{0}$ is the tool's number of teeth; $\beta_{0}$ is the inclination angle of the tool's tooth trace; $b_{0}$ is the width of the tool's ring gear; $\alpha_{n w 01}$ is the angle of engagement between tool and gear; $\alpha_{0}$ is the pressure angle at a point of the tool's tooth contour; $\mathrm{m}_{0}$ is the mass of the tool rim; $\mathrm{J}_{0}$ is the moment of inertia of the tool rim; $d_{a 0}$ is the diameter of the tool tip; $C_{\text {eng }}$ is the contact stiffness between tool and gear; $h_{\text {eng }}$ is the damping coefficient when tool and workpiece are engaged; $\mathrm{C}_{\text {cut }}$ is the stiffness of the cutting process; $\mathrm{h}_{\mathrm{cut}}$ is the damping coefficient in the shear zone; $\mathrm{M}_{\mathrm{cm}}$ is the mark of the workpiece material; $\mathrm{G}_{\mathrm{cm}}$ is the grain size of the workpiece material; $C_{c m}$ is the concentration of the workpiece material in the medium; $C_{m}$ is the coupling stiffness of the tool hub with the kinematic chain of the machine tool; $h_{m}$ is the damping stiffness of the tool hub's coupling with the kinematic chain of the machine tool; $\mathrm{C}_{\mathrm{sm}}$ is the coupling stiffness of the workpiece with the kinematic chain of the machine tool; $\mathrm{h}_{\mathrm{sm}}$ is the damping coefficient of the workpiece coupling with the kinematic chain of the machine tool.

When the structure $\Sigma$ of the technological system is changed, the set of parameters (13) is changed correspondingly. When the structure with multi-tool adjustment is used, the $\mathbb{X}_{\mathrm{tm}}, \mathbb{X}_{\mathrm{tw}}, \mathbb{X}_{\mathrm{nt}}, \mathbb{X}_{\mathrm{nk}}, \mathbb{X}_{\mathrm{kt}}, \mathbb{X}_{\mathrm{kw}}, \mathbb{X}_{\mathrm{wt}}, \mathbb{X}_{\mathrm{te}}$ parameter modules are structurally changed according to the number of tools. In the case of combined finishing, the $\mathbb{x}_{\mathrm{tm}}, \mathbb{x}_{\mathrm{nk}}, \mathbb{x}_{\mathrm{kw}}$, $\mathbb{X}_{\mathrm{kt}}, \mathbb{X}_{\mathrm{tw}}$ parameter modules have to be changed. However, the parametric model (12) as well as the structure of the graph $\mathbf{G}$ remain the same. The relations in the graph $\mathbf{G}$, describing the creation process of the model for the finishing of gears, can be formalized strictly. In so far as the relations can be formalized, the synthesis is provided by the principal method for solving project problems. This is done by a formalized search for optimum values of the characteristics (set of project parameters $\mathbb{X}$ ) desired for the technological system.

The methodology of the system design requires that the process of synthesis itself is considered as a system 2, 5 . Belonging to such a system model is the logical scheme for the design of technological systems - LSD TS. Even the synthesis process of technological systems for the finishing of gears is considered here as a totality of logically arranged project procedures and operations, seen from the point of view of the methodology for the system design. The decomposition of the initial task with regard to the synthesis of technological systems is carried out according to particular principles. These principles are formulated by experts on a corresponding subject area of the planning task.

The following principles are postulated in order to conduct the decomposition in the synthesis of technological systems for the finishing of gears 4 :

$>$ Resulting from their viability, correlations between real physical objects of the technological system for the finishing of gears are described as models of machine engagement by means of abstract objects of the information system. An optimization system follows from these models in such a way that the function of its objects guarantees the synthesis:

$$
\underset{\mathbb{M}}{\forall P} \underset{\mathbb{M}}{\exists} P:\left\{\left(R \Leftrightarrow I_{S}\right) \subset O_{S} \Rightarrow(\Sigma \wedge \mathbb{X})\right\},
$$

where $\mathrm{I}_{\mathrm{S}}$ and $\mathrm{O}_{\mathrm{S}}$ are the corresponding information and optimization systems;

$>$ By choosing a rational structure of the technological system and optimizing independent parameters of machine engagement, it is possible to realize the synthesis of technological systems for the machining of gears as intersection of its sets in the range of possible optimal values which are determined by the functioning of the optimization system and the boundary conditions:

$$
\underset{\mathbb{M}}{\forall P} \underset{\mathbb{M}}{\exists} P:\left\{(R \wedge \mathbb{X})\left[\left(\Sigma \stackrel{Q^{d}}{\Rightarrow} \Sigma\right) \wedge \operatorname{opt}(\mathbb{X} \cap \hat{\mathbb{Z}})\right]\right\},
$$

where $\hat{\mathbb{Z}}$ is the set of boundary conditions.

According to these demands, a decomposition of the original task is carried out with regard to the planning of technological systems for the finishing of gears. The extended tasks $Q_{11}-Q_{14}$ are selected on the first level (rough decomposition, $\mathrm{i}=l$ ). The task $\mathrm{Q}_{11}$ is solved in accordance with the developed parametric model of the finishing process (12). The task $\mathrm{Q}_{12}$ is solved in accordance with the structural-hierarchical models (8) and (10) as well as the graph $\mathbf{G}$. Consequently, the interactions of real physical objects in the technological system are described in accordance with the postulated principle of decomposition (14) by means of an abstract information system $\mathrm{Q}_{13}$. The optimization system (task $\mathrm{Q}_{14}$ ) is selected from the information system $\mathrm{Q}_{13}$ in accordance with the principle (15). The following fundamental principles are postulated for carrying out the second level of decomposition:

$>$ Serving as functional (sufficient) relations of the technological system are objects of an information system: models imitating the geometry of machine engagement, the formation of the tooth profiles of the gears to be cut, the dynamic interaction between members of the technological system as well as a regression model regarding the formation of the technological characteristics in the finishing of gears: 


$$
\underset{\mathbb{M}}{\forall P} \underset{\mathbb{M}}{\exists} P:\left\{\min \left(R_{I_{S}}\right) \Leftrightarrow\left(D_{G} \wedge D_{F} \wedge D_{D} \wedge D_{T}\right)\right\}
$$

where $\mathrm{R}_{\mathrm{IS}}$ are the relations of the information system; $\mathrm{D}_{\mathrm{G}}, \mathrm{D}_{\mathrm{F}}, \mathrm{D}_{\mathrm{D}}, \mathrm{D}_{\mathrm{T}}$ are the corresponding models imitating the geometry of machine engagement, the formation of the tooth profiles of the gears to be cut and the dynamic interaction between the members of the technological system as well as a regression models regarding the formation of the technological characteristics in the finishing of gears;

$>$ The local quality criteria reflecting the efficiency of the technological system are realized by means of objective functions. These objective functions are determined during the functioning of the imitation models. The local quality criteria reflecting the operating characteristics of the technological system are realized by means of regression models of the technological characteristics worked out in experimental tests:

$$
\underset{\mathbb{M}}{\forall} \underset{\mathbb{M}}{\exists} P:\left\{\left(\mathbb{F}_{I_{S}} \subset K_{i j}^{\mathrm{E}}\right) \wedge\left(F_{I_{S}} \subset K_{i j}^{\mathrm{D}}\right)\right\}
$$

where $\mathrm{F}_{\mathrm{IS}}$ is the set of objective functions; $K_{i j}^{E}, K_{i j}^{D}$ are the local quality criteria reflecting the efficiency and the operating characteristics of the gears to be cut.

On this level (second decomposition, $\mathrm{i}=2$ ), further specific tasks are selected: $\mathrm{Q}_{21}-\mathrm{Q} 2_{10}$. The third level of decomposition makes it possible to select very specific tasks: $\mathrm{Q}_{31}-\mathrm{Q}_{323}$. The solutions of such tasks are connected with the synthesis and can be formalized strictly. The sequence of the synthesis is established by a morphological model, which is constructed according to the scheme of decomposition. The morphological model establishes the sequence of the solution tasks on every level of decomposition. It is possible here to solve some tasks $Q_{i j}^{C}$ by means of mathematical models. The procedure for solving the other part of the tasks $Q_{i j}^{d}$ has to be realized in an interactive mode. In addition to that, there are mixed tasks - $Q_{i j}^{f d}$. The morphological model for the synthesis of technological systems for the finishing of gears is established by the predicate system of the corresponding level of decomposition:

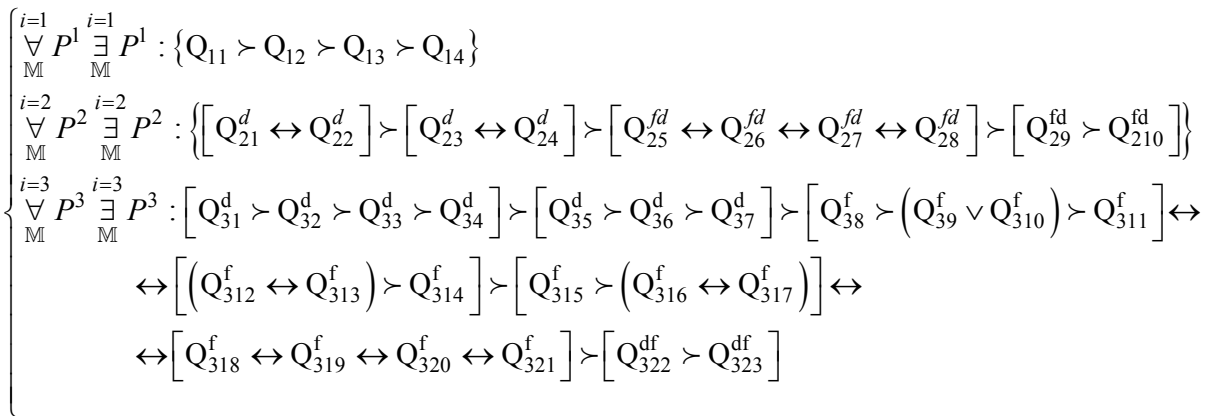

where $\leftrightarrow$ is the symbol of the compatibility relation 3 .

The LSD TS can formally be represented as relations $\mathrm{H}_{\mathrm{Q}}$ and $\mathrm{B}_{\mathrm{Q}}$ from the group of sets $\mathrm{Q}$, of which the elements correspond to a selected set. The selection of the set is presented as a result of decomposing the initial task $\mathrm{Q}_{\mathrm{ij}}$, where I is the number of the initial task's decomposition level and $\mathrm{j}$ is the serial number of the task on the $i$ th level. The correlations HQ are valid for tasks of different levels, because if $\mathrm{Q}_{\mathrm{irjq}} \mathrm{H}_{\mathrm{Q}} \mathrm{Q}_{\mathrm{iwjv}}$ is true, then the task $\mathrm{Q}_{\mathrm{iwjv}}$ is part of the task

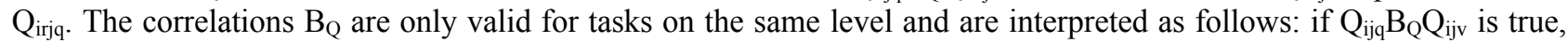
then it is impossible to solve the task $\mathrm{Q}_{\mathrm{ijv}}$ satisfactorily without prior solution of the task $\mathrm{Q}_{\mathrm{ijq}}$. For any task $\mathrm{Q}_{\mathrm{ij}}$ that represents a cell of LSD TS, it is necessary to establish input data $A_{i j}$, boundary conditions $C_{i j}$, project solutions $R_{i j}$, solution procedures $\mathrm{T}_{\mathrm{ij}}$ and the model of the task $\mathrm{M}_{\mathrm{ij}}$ :

$$
Q_{i j}=\left\{A_{i j}, C_{i j}, R_{i j}, K_{i j}, T_{i j}, M_{i j}\right\} .
$$

The conclusion of solutions $\mathrm{R}_{\mathrm{ij}}$, which is shown in the output design documentation, is realized by using the model $\hat{M}$ of the project object. The scheme of function for a cell of LSD TS can be presented with the following formula:

$$
T_{i j}:\left\{A_{i j}, C_{i j}, K_{i j}\right\} \stackrel{M_{i j}}{\rightarrow} R_{i j} \rightarrow \hat{M}
$$

Similar to the formula (20), every task is represented that exists as a part in the morphological model on the corresponding level of decomposition. The general structure LSD TS is constructed according to the morphological model (18). Fig. 8 shows a fragment of the solution for the task $\mathrm{Q}_{11}$ - "Analysis of the demands on the finished component and the technological system". The whole structure of the LSD TS is constructed analogous to this fragment.

An analysis of the proposed method showed that it is necessary to work out the following basic stages for carrying out the synthesis of technological systems for the finishing of gears:

$\checkmark$ Decomposition of the initial task - D IDP; 
$\checkmark \quad$ Construction of the morphological model LSD TS - $\mathrm{D}_{\mathrm{m}}$;

$\checkmark \quad$ Elaboration of an information system IS describing the relations of objects in the technological system;

$\checkmark$ Elaboration of an optimization system $\mathrm{O}_{\mathrm{S}}$ which is selected from the information system;

$\checkmark \quad$ Construction of a general structure of LSD TS as a unit of cells - DLSD (20);

$\checkmark$ Elaboration of an algorithmic system $\mathrm{A}_{\mathrm{s}}$, presenting a general algorithm for the synthesis of the technological system.

Hence, the procedure for constructing the LSD TS model for the finishing of gears can be described with the following logical structure:

$$
D_{I D P} \Rightarrow D_{m} \Rightarrow I_{S} \Rightarrow O_{S} \Rightarrow D_{L S D} \Rightarrow A_{S} .
$$

According to the logical structure (21), an information and optimization system as well as an algorithmic system is to be worked out for realizing the synthesis of technological systems. In the first stage of the synthesis of technological systems for the finishing of gears, a model imitating the geometry of machine engagement between a tool and a gear to be cut is developed according to the decomposition principles of the initial task.

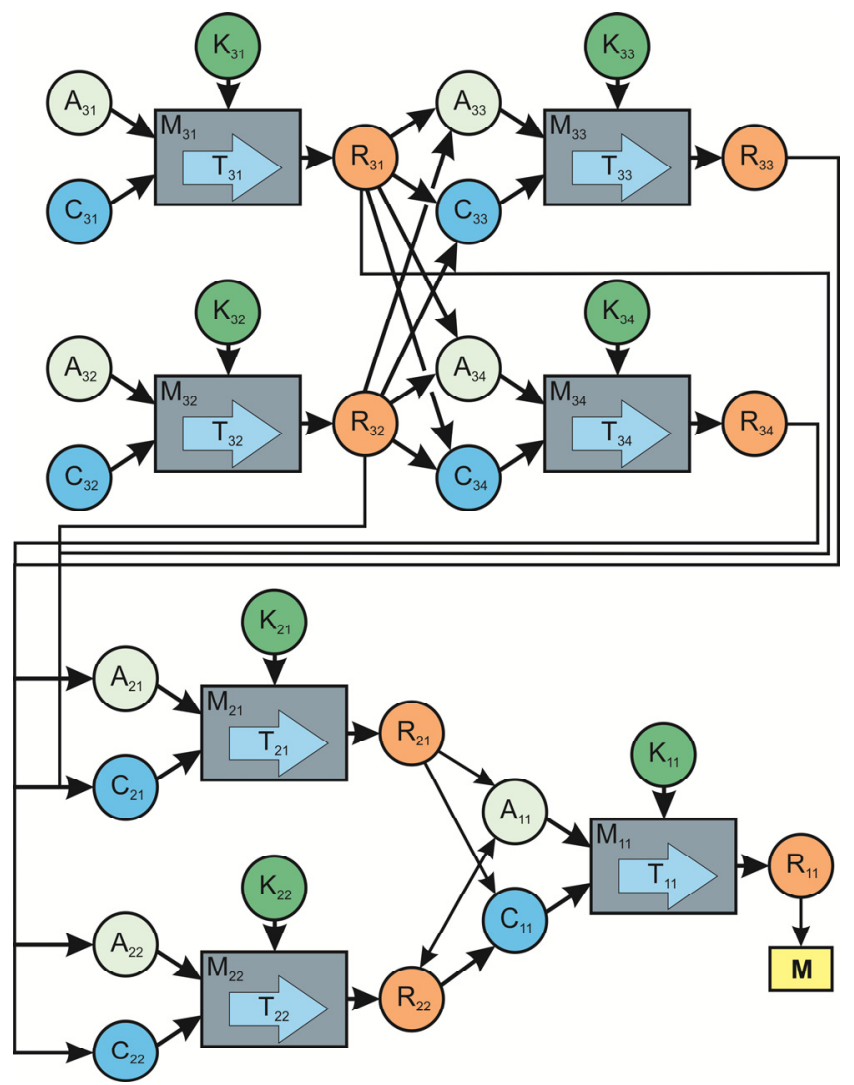

Fig. 8. Fragment of the general structure of the design scheme regarding the technological system for gear finishing

\section{Conclusion}

The method of technological systems synthesis for the finishing processing of gears is implemented in the form of a logical design scheme of technological systems - LSD TS. This scheme is interpreted by a morphological model developed by decomposing the original design problem and regulating the synthesis process, informational, optimization, and algorithmic systems.

The information system is based on simulation models of the geometry of the machine gearing, shaping the teeth profile of gear and the dynamic interaction of the links and the full-scale model of the formation of the technological characteristics of the machining process (errors of the ring gear and the quality of the surface layer of the teeth).

The full-scale model of the formation of the technological characteristics of the processing process was obtained on the basis of experimental studies.

The optimization system is pick out from the information system in accordance with the LSD TS. This is implemented by determining the vector of objective functions as the result of the functioning of the models of the information system, the vector of system quality criteria, the vector of independent design parameters and the vector of constraints. The presence of these objects of the optimization system allows us to develop an algorithmic system whose objects are: an algorithm for structural optimization, based on the method of searching the known structures of technological systems from a data bank created as a result of expert assessments and rank correlations of the board of specialists; software implemented parametric optimization algorithm based on the LP-search method for optimal values of parameters of information system models. 
Using an algorithmic system allows you to select a rational structure of the technological system and perform multi-parameter optimization.

As a result, the region of optimal values of design parameters of elements of the technological system is determined. The last two elements provide identification of the desired technological systems and are the main result of the developed method of synthesis.

\title{
Розробка принципів проектування технологічних систем для опоряджувальної обробки зубчастих колес
}

\author{
М.Г. Сторчак, Ю.М. Данильченко
}

Анотація. Експлуатаційні властивості зубчастих коліс переважно формуються під час їх опоряджувальної обробки із застосуванням різних прочесів, таких як зубошліфування, зубошевінгування, зубохонінгування, притирання, припрачювання тощо. Основним завданням синтезу технологічних систем опоряджувальної обробки зубчастих коліс $\epsilon$ визначення оптимальних параметрів та структури технологічної системи, що забезпечують задані властивості зубчастих коліс. Це завдання багатоваріантне і ускладнене відсутністю загальних принципів його вирімення, щьо обумовлює індивідуальний підхід до проектування технологічних систем різних процесів. Запропоновані принципи проектування технологічних систем на основі системного підходу забезпечують вирішення завдання їх синтезу для опоряджувальної обробки загалом, тобто иляхом представлення технологічної системи, як узагальненого об’єкту проектування. Метод синтезу реалізовано у вигляді логічної схеми проектування, яка інтерпретується морфологічною моделлю. Ця модель розроблена шляхом декомпозииї вихідного завдання проектування та регламентує процес синтезу інформаційної, оптимізаційної та алгоритмічної систем об'єкту проектування незалежно від виду опоряджувальної обробки.

Ключові слова: Зубчасті колеса, технологічна система, синтез, системний підхід, морфологічна модель.

\section{Разработка принципов проектирования технологических систем для отделочной обработки зубчатых колес}

\author{
М.Г. Сторчак, Ю.М. Данильченко
}

Аннотация. Эксплуатационные свойства зубчатых колес в основном формируются на этапах их отделочной обработки с применением различных прочессов, таких как зубошлифование, зубочевингование, зубохонингование, притирка, приработка и т. п. Основной задачей синтеза технологических систем отделочной обработки зубчатых колес является определение оптимальных параметров и структуры технологической системы, обеспечивающих заданные свойства зубчатых колес. Эта задача многовариантная и усложненная отсутствием общих приниипов ее решения, что обуславливает индивидуальный подход к проектированию технологических систем для различных проиессов. Предлагаемые принципы проектирования технологических систем на основе системного подхода обеспечивают решение задачи их синтеза для отделочной обработки вообще, то есть путем представления технологической системы в виде обобщенного объекта проектирования. Метод синтеза реализован в виде логической схемы проектирования, которая интерпретируется морфологической моделью. Эта модель разработана путем декомпозиции исходной задачи проектирования и регламентирует прочесс синтеза информаџионной, оптимизаџионной и алгоритмической систем объекта проектирования независимо от вида отделочной обработки.

Ключевые слова: Зубчатые колеса, технологическая система, синтез, системный подход, морфологическая модель.

\section{References}

1. Arnold, R.D., Wade, J.P. A Definition of Systems Thinking: A Systems Approach. Procedia Computer Science. - 2015, Vol. 44, P. 669 - 678. https://doi.org/10.1016/j.procs.2015.03.050

2. Bertalanffy, L.V. General System Theory: Foundations, Development, Applications. New York: George Brazillier Inc., 2015. $-304 \mathrm{p}$.

3. Kleene, S.C. Mathematical Logic. Dover, 2001. -432 p.

4. Storchak, M. Technological Systems for Finishing Gears. Institute for Superhard Materials, - 1994. - Kiev, Ukraine.

5. Uemov, A.I. Methods for building and developing a general theory of systems. Nauka, Moscow, 1971, $-18 \mathrm{p}$.

6. Ropohl, G.: Allgemeine Systemtheorie: Einführung in transdisziplinäres Denken. edition sigma, 2012, -246 p.

7. Hubig, C. Nachdenken über Technik: Die Klassiker der Technikphilosophie und neuere Entwicklungen. Sigma, 2013.-546 p.

8. Luhmann, N. Einführung in die Systemtheorie. Auer-System-Verlag Carl, 2017, - 334 p.

9. Thurner, S., Hanel, R. and Klimek, P. Introduction to the Theory of Complex Systems. Oxford University Press, 2018. $-448 \mathrm{p}$

10. Morin, E. On Complexity (Advances in Systems Theory, Complexity, and the Human Sciences). Hampton Press, 2008. $127 \mathrm{p}$. 